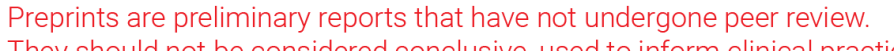 \\ They should not be considered conclusive, used to inform clinical practice, or referenced by the media as validated information. \\ Endogenous Calcium Mediated The Seedling Growth And Fluoride Stress Tolerance In Four Bean Genotypes
}

\section{Sara Chahine}

University of Sassari

Sara Melito ( $\boldsymbol{D}$ smelito@unina.it)

University of Sassari https://orcid.org/0000-0002-4910-2353

Vittoria Giannini

University of Sassari

Pier Paolo Roggero

University of Sassari

\section{Giovanna Seddaiu}

University of Sassari

\section{Research Article}

Keywords: Fluoride stress, translocation factor, tolerance index, salt stress.

Posted Date: November 2nd, 2021

DOI: https://doi.org/10.21203/rs.3.rs-931646/v1

License: (9) This work is licensed under a Creative Commons Attribution 4.0 International License. Read Full License 


\section{Abstract}

Fluoride (F) pollution is a global environmental problem representing a severe risk for food and vegetables grown in contaminated soils. Phaseolus vulgaris $\mathrm{L}$. is widely cultivated in arid and semi-arid regions and in $\mathrm{F}$ contaminated areas of the world. $\mathrm{F}$ tolerance during germination and seedling growth was evaluated for four bean ecotypes: Borlotto nano and three African genotypes (Lyamungu 85, Lyamungu 90 and Jesca).

Seeds were grown in sand enriched with $\mathrm{NaF}$ or KF at three different levels $\left(0,80\right.$ and $\left.200 \mathrm{mg} \mathrm{kg}^{-1}\right) . \mathrm{NaCl}$ was used as a benchmark to determine a potential effect of different $\mathrm{Na}$ levels in plant. Total $\mathrm{F}$ content and minerals accumulation ( $\mathrm{Na}, \mathrm{K}$ and $\mathrm{Ca}$ ) in roots and shoots were measured. The translocation factor, growth ratio, $\mathrm{F}$ tolerance index were evaluated to estimate plant-salt response. Germination rate decreased with increased $\mathrm{F}$ level. Borlotto was more $\mathrm{F}$ sensitive ( $0 \%$ germination with $200 \mathrm{mg} \mathrm{kg}^{-1}$ of KF and $\mathrm{NaF}$ ) than African genotypes. Under the highest $\mathrm{F}$ concentration $\left(200 \mathrm{mg} \mathrm{kg}^{-1}\right), \mathrm{F}$ preferentially accumulated in shoots (Jesca $75.7 \mathrm{mg} \mathrm{kg}^{-1}$, Lyamungu $85100.1 \mathrm{mg} \mathrm{kg}^{-1}$ and Lyamungu $90115.4 \mathrm{mg} \mathrm{kg}^{-}$ ${ }^{1}$ ). Ca content in roots was negatively correlated to $\mathrm{F}$ absorption, suggesting its antagonistic role to $\mathrm{F}$ mobility.

Based on these parameters, Jesca and Lyamungu 85 were the most tolerant species recording a low $\mathrm{F}$ uptake and a high $\mathrm{Ca}$ content in the root. This study highlighted the central role of $\mathrm{Ca}$, as a key secondary messenger in regulating the plant growth and development under $\mathrm{F}$ stress.

\section{Introduction}

Fluorine contamination of soil and groundwater represents a serious risk for human health in several countries. The maximum permissible limit of fluoride $(F)$ in drinking water is $1.5 \mathrm{mg} \mathrm{L}^{-1}$, (WHO, 1984). However, there is no stringent threshold limit of $\mathrm{F}$ content in soil and plant tissues above which the ingestion is considered to be detrimental to human health. In America, Asia, Middle East, and Africa, people consume water with fluoride concentration greater than $1.5 \mathrm{mg} \mathrm{L}^{-1}$ (Frencken, 1992). Contaminated soils pose a threat on human, animal and plant health. Although $\mathrm{F}$ is considered an essential element to animal diet to improve bone and teeth development, excessive $F$ in the diet can cause harmful alterations to teeth, bone and other body systems (Loganathan et al. 2003). The excess $\mathrm{F}$ in water, air and soils is caused by weathering of volcanic ashes (Cronin et al. 2003), application of phosphate fertilisers and the (illegal) release of industrial wastes (Choubisa and Choubisa, 2016).

In nature, fluorine forms $\mathrm{F}$ water-soluble compounds such as sodium fluoride $(\mathrm{NaF})$ or other alkali-metal fluorides such as potassium fluoride (KF). Moreover, it can also be part of some non-dissociated salts such as calcium fluoride $\left(\mathrm{CaF}_{2}\right)$ also known as fluorite or fluorspar. The toxicity of $\mathrm{F}$ and its cumulative effects depend on the species susceptibility, the duration of the exposure to F, over the solubility of the $F$ salt. 
High level of F inhibits seed germination and early growth of many plants (Elloumi et al. 2005; Gupta et al. 2009), inducing several morphological symptoms like chlorosis, tip and marginal necrosis (Dey et al. 2012; Fornasiero, 2003). F absorbed from soil is translocated to the shoots, causing physiological, biochemical and structural damages, depending on its concentration in the substrate and its translocation from roots to shoots (Dey et al., 2012). A high concentration of $F$ adversely affects growth and survival of plants as a consequence of its inhibitory effects on respiration, photosynthetics pigments (Kamaluddin and Zwiazek, 2003), mineral and water uptake and enzymes activity (Fornasiero, 2003).

Sensitivity to $F$ is highly species-dependent (Beast and Haeck, 1983), indeed some plants are able to accumulate $\mathrm{F}$ at higher concentrations (up to $4000 \mu \mathrm{g} \mathrm{g} \mathrm{g}^{-1}$ ) displaying no sign of toxicity (Jha et al., 2008), while other show signs of toxicity at much lower concentration although some species are enormously sensitive to a level $<20 \mu \mathrm{g} \mathrm{g}^{-1}$ (Jha et al., 2008).

Common bean (Phaseolus vulgaris L.) is an important herbaceous annual grain legume, grown as a cheap source of protein, good carbohydrates and iron among the majority of Sub-Saharan African countries. Tanzania ranks fifth worldwide in bean production and is the leading producer of beans in Africa (FAOSTAT, 2014). The common bean varieties grown are Tikyakuponza, Soya, Lyamungu-85, Lyamungu-90, Canadian Wonder, Selian-94, Masai Red, Jesca, and Calima (Katungi et al. 2009). However, a high proportion of agricultural land in Tanzania is contaminated by $\mathrm{F}$ of volcanic origin as it happens across many districts of the Rift Valley in East Africa.

While many studies explored the plant response to $\mathrm{NaCl}$ salinity, fragmented information is available on plant tolerance to F. Nevertheless, the processes and mechanisms behind $\mathrm{NaCl}$ plants' adaptative methods could be useful to paving the way for an investigation into the adaptation strategies of plants to F. Many studies revealed that the ability of plant genotypes to maintaining higher levels of $\mathrm{K}$ and $\mathrm{Ca}$ and low levels of $\mathrm{Na}$ and $\mathrm{Cl}$ within the tissues is one of the critical mechanisms contributing to high salt tolerance. In the screening of plant genotypes for salt tolerance, the shoot $\mathrm{K}: \mathrm{Na}$ and $\mathrm{Ca}: \mathrm{Na}$ ratios and tissue $\mathrm{Na}$ concentration have often been proposed as a useful screening tool to assess the salt tolerance of different crop species (Aktas et al. 2006; Shabala and Cuin, 2008).

Starting from these milestones, three common bean African genotypes and one commercial variety were selected to compare the effect of different sources of $\mathrm{F}(\mathrm{NaF}$ and KF) in selected morpho-physiological traits and principal mineral contents. We hypothesized that the effects of excess $F$ content and of other ions $\left(\mathrm{Ca}^{2+}, \mathrm{K}^{+}, \mathrm{Na}^{+}\right)$in the substrate is different in commercial and African bean varieties currently grown in F-rich soils and that these effects can be detected in the early growth stages of beans, which are crucial for subsequent plant growth, development and yield. The objective of the experiment was to study (i) the effects of increasing $F$ levels in the substrate on germination and seedling growth traits of African bean genotypes; (ii)the possible different response of African bean genotypes to $\mathrm{F}$ at the seedling level; (ii) the contribution of ion accumulation to the osmotic adjustment and the role of $\mathrm{Na}, \mathrm{K}$ and $\mathrm{Ca}$ homeostasis in the determination of salt tolerance; (iii) the possible differences of ion profiles under $\mathrm{F}$ between the shoots and the roots. 
To the best of our knowledge, this is the first study on early development stages of different bean genotypes as influenced by increasing exposure to F-based salts. The ultimate aim was to contribute to the rapid identification of promising genotypes which can be used for selection of F-tolerant bean varieties i.e. able to grow in F-rich soils and to minimize the $\mathrm{F}$ absorption and translocation in edible plant organs.

\section{Material And Methods}

\section{Plant material and experimental conditions}

Mature seeds of four bean (Phaseolus vulgaris L.) genotypes were used for the germination experiments. Three African genotypes Lyamungu 85 (LYA85); Lyamungu 90 (LYA90); Jesca (JES) (provided by the Nelson Mandela University of Science and Technology in Tanzania) and the commercial cultivar Borlotto nano (BOR) were used. The experiment was carried out in a growth chamber $\left(24 \pm 2^{\circ} \mathrm{C}, 18 \mathrm{~h}\right.$ photoperiod, with an average irradiance of 1500 lux) for 14 days.

Three salt sources were added to the germination substrate (silica sand): sodium fluoride (NaF); potassium fluoride (KF) and sodium chloride $(\mathrm{NaCl})$ and for each salt, three levels were evaluated: 0 (Control), $80 \mathrm{mg} \mathrm{kg}^{-1}$, and $200 \mathrm{mg} \mathrm{kg}^{-1}$; treatment were reported as salt name and level (i.e. $\mathrm{KF} 80 \mathrm{mg}$ $\mathrm{kg}^{-}$, is reported as KF80) The choice of salt concentration levels was based according to the range of soil F contents observed in F-rich sites of the East African Rift Valley in Tanzania as reported by Rizzu et al. (2020). Control (F0) contain only silica sand. Plastic containers $(58 \times 72 \mathrm{~mm})$ containing two seeds each were used for each salt* level* variety combination, 15 replicates (containers) were used for each treatment. experiment was repeated twice.

During the experiment, irrigation was performed adding $5 \mathrm{~mL}$ of water in each box every 24 hours. The $\mathrm{F}$ and $\mathrm{Na}^{+}$contents in the enriched sand were monitored with the potentiometric method with an ionselective electrode (ORION 4 star) and inductively coupled plasma (ICP) atomic emission spectrometry (PerkinElmer), respectively.

\section{Germination and growth measurements}

The germination was recorded daily. Seedlings with a hypocotyl-radicle axis $>3 \mathrm{~cm}$ were considered as germinated. The proportion of germination was calculated using Eq. 1. After 14 days, the seedlings were gently washed with water to remove the sand, and the plant was scanned using a Mustek flatbed scanner (model A3 USB 1200S). The length of the aerial part (L-AP) was measured using the Image $\mathrm{J}$ software (Image processing and analysing in Java). Root length (R-L) was estimated with the GIA ROOTS software (Galkovskyi et al. 2012).

Seedlings were wrapped in labelled blotting paper, oven-dried at $65^{\circ} \mathrm{C}$ until constant weight. Aerial part $(A P)$ and root $(R)$ dry weight (DW) were measured. Germination percentage (\%G)(Eq. 1), growth ratio (GR) (Eq. 2) and F tolerance index (TI) (Eq. 3) were calculated using the following equations (Baker, 1983): 
$\% G=\frac{\text { no. seedsgerminated }}{\text { Totalno } . \text { seeds }} * 100$ (Eq. 1)

$G R=\frac{\text { Plantbiomasswithsalt }}{\text { Plantbiomasswithoutsalt }} * 100($ Eq. 2)

$T I=\frac{\text { Rootlengthwithsalt }}{\text { Rootlengthwithoutsalt }}$ (Eq. 3)

\section{Determination of F content in root and shoot}

The total F content was estimated with an acid digestion method and subsequently quantified by $\mathrm{F}$ ionselective electrode (Rizzu et al. 2020).

The lyophilised samples $(150 \mathrm{mg})$ were weighed in a Teflon reactor and were then subjected to a microwave-assisted wet digestion process (Milestone Ethos Easy), using $65 \% \mathrm{HNO}_{3}(2 \mathrm{~mL}), 3 \mathrm{ml}$ of hydrogen peroxide and $5 \mathrm{ml}$ of dehydrogenised water. The power applied was $800 \mathrm{~W}$ and the program used was: step 1: ramp from room temperature to $200^{\circ} \mathrm{C}$ for $15 \mathrm{~min}$; step 2: hold at $200^{\circ} \mathrm{C}$ for $15 \mathrm{~min}$; step 3: cool to room temperature. When the Teflon reactor had cooled, the digestate was kept in a refrigerated bath $\left(-30^{\circ} \mathrm{C}\right)$ for $30 \mathrm{~min}$ to avoid loss of $\mathrm{F}$ in the form of $\mathrm{HF}$, then adjusted to a $\mathrm{pH}$ close to 7 using sodium hydroxide solution $\left(\mathrm{NaOH}, 8 \mathrm{~mol} \mathrm{I}^{-1}\right)$. Then the extraction solution was mixed with $10 \%(\mathrm{v} / \mathrm{v})$ of total ionic strength adjustment buffer "TISAB II" solution. The mixture was analysed by an ion-selective electrode (ORION 4 star). The digestion was applied at least in duplicate to each of the samples analysed.

Translocation factor (TF) was calculated for $F$ as:

$T F=\frac{\text { Fconcentrationinshoot }}{\text { Fconcentrationinroot }}($ Eq. 4)

\section{Macro and Micro-nutrients Content}

Minerals ( $\mathrm{Na}, \mathrm{K}$, and $\mathrm{Ca}$ ) were extracted with perchloric acid digestion (Maggio et al. 2000). Concentrations of minerals were analysed by inductively coupled plasma (ICP) atomic emission spectrometry (PerkinElmer).

\section{Statistical analysis}

The experiment was laid out as a completely randomized design with fifteen replicates. After having checked the main assumption of ANOVA, the not-normally distributed data (Na-AP, Na-R, K-R, K/ Na (AP), $\mathrm{Ca} / \mathrm{Na}(\mathrm{AP})$ were transformed using bounded distribution Sb, F-AP was transformed using Log-normal distribution SL while we calculated the arcsine of the square root of the percentage of germination (\%G) then it was transformed to normalised data using unbounded distribution (George and Ramachandran 2011). A two-way ANOVA was performed (Minitab 17 Statistical Software 2010).

When significant effects were observed $(P<0.01)$, multiple comparisons were investigated with the Tukey post-hoc test $(P<0.01)$. The histograms were presented as averages and standard error. 


\section{Results}

\section{Germination study}

A significant decrease of germination percentage $(G \%)$ was observed for all genotype as a consequence of the $\mathrm{F}$ treatment used $(P<0.0001)$ (Table 1). Under both $\mathrm{KF}$ and $\mathrm{NaF}$ treatments with $80 \mathrm{mg} \mathrm{kg}^{-1}$ of F, a significant reduction of germination was observed. Among genotypes under comparison, LYA 85 and JES showed the highest G\% under $\mathrm{NaF} 80$ and KF 80 , respectively (100\% and $93 \%$ ). Under both $\mathrm{KF}$ and $\mathrm{NaF}$ treatments with $200 \mathrm{mg} \mathrm{kg}^{-1}$ of $\mathrm{F}$, the germination was significantly affected for all the genotypes. Using $\mathrm{KF}$, the African bean genotypes survived with a low G\% (7-28\%), while no germination occurred using NaF. Nevertheless, with $\mathrm{NaCl} 200 \mathrm{mg} \mathrm{L}^{-1}, \mathrm{G} \%$ for LYA 85 and LYA90 did not statistically differ from control (100\%), while for BOR and JES it was significantly lower (93\%).

\section{Effect of $F$ on plant growth}

The effects of $\mathrm{F}$ treatments on the AP and $\mathrm{R}$ length and biomass in $P$. vulgaris seedlings were explored using two parameters: tolerance index (TI) and growth ratio (GR) (Table 2). All beans' genotypes were more tolerant to KF than $\mathrm{NaF}$, and a significant effect of the treatment level was observed $(P<0.0001)$. Beside the treatment, also the genotype differentially responded to the $\mathrm{F}$ treatments $(P<0.01)$. BOR was the most susceptible variety, and TI value was computable until $80 \mathrm{mg} \mathrm{kg}^{-1}(0.72$, and 0.76 respectively for KF and NaF). Indeed, BOR seeds did not germinate under NaF200 and KF200. LYA90 showed the highest TI value (1.04 and 0.94) under KF80 and NaF80, respectively (Table 2). Under KF200, the African genotypes showed a significant decrease in TI values (JES: 0.52, LYA85: 0.49 and LYA90: 0.62). A slight decrease of TI was observed for both BOR and JES under $\mathrm{NaCl} 200$, while it remained unchanged for LYA85 and increased for LYA90 (Table 2).

As observed for Tl, also GR\% was significantly affected by the treatments and genotypes $(P=0.0091 ; P$ $<0.0001$, respectively). GR\% for BOR followed the same trend observed for TI. In addition, under KF80, both JES and LYA90 (76\%) showed the lowest GR\%, while under NaF80, GR\% was much lower for JES (48\%) and LYA85 (59\%). Under KF200, LYA 90 showed the lowest GR (62\%). In contrast, JES showed the lowest GR \% under $\mathrm{NaCl} 200$ (74\%) (Table 2).

The DW showed a different trend for R and the AP with highly significant differences $(P<0.0001)$ (Table 3). DW-R decreased drastically with $F$ salt concentration (Table 3$)$. The effect of $F$ treatments $(80 \mathrm{mg} \mathrm{kg}$

${ }^{-1}$ ) were much more negative on roots than on the aerial part. Under $\mathrm{NaF} 80$, the highest DW-R reductions were registered (BOR 50\%, JES 79\%, LYA85 69\% and LYA90 47\%), while moderate reductions were observed under KF80 (BOR 40\%, JES 39\%, LYA85 16\% and LYA90 40\%). Under KF200, DW-R decreased respectively by $50 \%$ (JES), 76\% (LYA85) and 73\% (LYA90), while the parameter was not computed for BOR since there was not germination. Under $\mathrm{NaCl} 200$, the highest decline observed was for JES (44\%) and LYA90 (31\%). In the present study, the R/AP dry weight ratio decreased in all the treatments except for $\mathrm{NaCl} 80$ in BOR and JES compared to the control. This indicated that the R/AP of all genotypes 
responded in a similar manner to the treatments except for BOR and JES at NaCl 80. LYA 85 and LYA90 showed the highest ratio under $\mathrm{NaCl} 200$ (Table 3).

The highest R/AP ratio was observed in JES under KF200 and in LYA90 under NaF 80 treatment, while the lowest was observed in LYA85 under KF200 and in JES and BOR under NaF 80.

\section{Fluoride uptake}

Overall, the type of salt (treatment) and salts concentrations (treatment levels) had a significant impact on $\mathrm{F}$ tissue content, while no genotype effect was observed. Under F0, LYA90 showed the highest F content in AP (8.15 $\left.\mathrm{mg} \mathrm{kg}^{-1}\right)$ while BOR in $\mathrm{R}\left(6.75 \mathrm{mg} \mathrm{kg}^{-1}\right)$ (Table 4).

Under KF 80, no significant differences were recorded in terms of $\mathrm{F}$ accumulation among all the genotypes for both AP and R. (Table 4)

Under KF treatments, JES accumulated the lowest F amount at KF 200 when compared to F0 $(73.3 \mathrm{mg}$ $\left.\mathrm{kg}^{-1}\right)$ in the AP, while LYA 90 accumulated the highest $F$ content $\left(107.3 \mathrm{mg} \mathrm{kg}^{-1}\right)$. On the other hand, LYA 90 and JES took up the lowest quantity of $F$ in their R when comparing KF200 to F0 (+32.8 mg kg-1 and $+43.6 \mathrm{mg} \mathrm{kg}^{-1}$ respectively). LYA 85 instead accumulated $+62.2 \mathrm{mg} \mathrm{kg}^{-1}$ of F with KF200 compared to F0 in R. (Table 4).

About $\mathrm{NaF}$, the only data available is the treatment with $80 \mathrm{mg} \mathrm{kg}^{-1}$, since higher concentration of salt inhibited the germination. BOR was able to accumulate the greatest quantity of $F$ in AP compared to the other genotypes, reaching the value of $37.2 \mathrm{mg} \mathrm{kg}^{-1}$. In general, all African bean genotypes accumulated less $\mathrm{F}$ in both organs compared to BOR, absorbing probably less $\mathrm{F}$ from the enriched $(\mathrm{NaF})$ substrate used. LYA 85 accumulated the lowest amount of $F$ compared to the other bean genotypes (17.67 and $10.98 \mathrm{mg} \mathrm{kg}^{-1}$ in AP and $\mathrm{R}$, respectively). (Table 4).

Based on the TF, all the genotypes studied showed a high ability to translocate $\mathrm{F}$ to the aerial part accordingly to the increased concentration of $F$ (KF200). Under treatments supplying $80 \mathrm{mg} \mathrm{kg}^{-1}$ of $F$, JES was the only variety recalcitrant to translocate $F$ to its AP (0.6) while LYA85 and BOR were able to transfer the $F$ to the aerial part (BOR 1.3 and LYA85 1.8) (Fig. 1).

\section{Ion's concentrations}

$\mathrm{Na}$ and $\mathrm{Ca}$ cations distribution in R and AP tissues were studied in all genotypes. Na content varied significantly among organs $(\mathrm{R}$ and $\mathrm{AP})$ and treatment $(\mathrm{P}<0.0001)$. As expected, under $\mathrm{NaF}$ and $\mathrm{NaCl}$, organs showed a higher level of $\mathrm{Na}$ compared to FO and KF treatments. In all genotypes, Na content in both $\mathrm{R}$ and $\mathrm{AP}$, significantly increased with the increased level of $\mathrm{Na}$ supplied through $\mathrm{NaF}$ and $\mathrm{NaCl}$. $\mathrm{Na}$ content under $\mathrm{NaF}$ was significantly higher than under $\mathrm{NaCl}$ salt, with the highest level reached for JES and LYA85 (500\%-516\%) under $\mathrm{NaF} 80$. Conversely, under $\mathrm{NaCl} 80$, the highest levels were observed for BOR (199\%) and JES (157\%) (Fig. 2A). 
All genotypes showed a significant dose-dependent increase of $\mathrm{Na}$ content in AP, with increased $\mathrm{NaF}$ and $\mathrm{NaCl}$ stress. Using $\mathrm{NaF}$ salt, plants accumulated more $\mathrm{Na}$ than with $\mathrm{NaCl}$ treatment (Fig. 2): the highest $\mathrm{Na}$ content was reached for JES under $\mathrm{NaF} 80$ and $\mathrm{NaCl} 80$ respectively $584 \%$ and $433 \%$ (Fig. 2B). With KF 80 treatment we observed a reduction in Na content in AP for BOR, JES, and LYA90 of $43 \%, 28 \%$, and $15 \%$, and an increase for LYA85 of $12 \%$.

In R, Ca content decreased by the same level with KF80 $\mathrm{mg} \mathrm{kg}^{-1}$ treatment in BOR, JES and LYA90 by 34\%, $38 \%$ and $31 \%$ respectively while for LYA85 it decreased only by $11 \%$. Ca content in roots did not change for LYA85 under NaF 80 ; in contrast, it decreased by $43 \%$ for BOR, $44 \%$ for JES and $34 \%$ for LYA90. BOR and JES showed a similar trend in Ca content in R under NaF treatment. Under KF200, JES showed the highest decrease (by 74\%). Under $\mathrm{NaCl} 200$, no changes were observed for JES and LYA90, while an increase was recorded for BOR and LYA85 (Fig. 3).

A similar trend was observed in AP. Both under KF80 and NaF 80, Ca decreased significantly. More in detail, under KF80 it decreased by $36 \%$ in BOR, $28 \%$ in JES, $19 \%$ in LYA85 and $29 \%$ in LYA90, while under NaF80 it decreased by $52 \%$ in BOR, $13 \%$ in JES, $30 \%$ in LYA85 and $40 \%$ LYA90. LYA 85 was again the genotype with the highest $\mathrm{Ca}$ content in AP under $\mathrm{F}$ treatments. However, $\mathrm{Ca}$ content in the AP showed a continuous increase with $\mathrm{NaCl}$ treatment (44\% BOR, 99\% JES, 43\% LYA85 and 65\% LYA90 at NaCl80 (Fig. $3)$.

The $\mathrm{Ca} / \mathrm{Na}$ ratio in AP decreased in all genotypes and treatment except for BOR and JES under KF 80 . The lowest ratio was 0.88 for LYA85 under KF200 (Table 4). All genotypes exhibited a low $\mathrm{Ca} / \mathrm{Na}$ ratio in AP with the lowest content under KF200 and NaF80. As a consequence of a greater increase in $\mathrm{Na}$ and decreased $\mathrm{K}$ concentration under both $\mathrm{NaCl}$ and $\mathrm{NaF}$ treatment, the $\mathrm{K} / \mathrm{Na}$ ratio in $\mathrm{AP}$ decreased in response to the increased salt level. Indeed, the lowest decrease was observed for LYA85 under KF200 and $\mathrm{NaCl} 200$. Under $\mathrm{NaF}$, no difference in terms of genotypes was recorded. In root, JES showed an increase in K/Na compared to the other African bean genotypes under KF200, while JES showed the lowest ratio under $\mathrm{NaF} 80$ (Table 5).

The bean genotypes which showed the highest $\mathrm{Ca} / \mathrm{Na}$ ratios were the most tolerant to $\mathrm{F}$ stress, and the most sensitive showed the lowest $\mathrm{K} / \mathrm{Na}$ ratios. Our results showed that $\mathrm{K} / \mathrm{Na}$ ratio decreased (especially in roots) through salt-treated plants and Na was more concentrated in roots than in the aerial part. JES showed the highest $\mathrm{K} / \mathrm{Na}$ ratio in AP, thus revealing higher capability of storing the toxic ions as $\mathrm{Na}$ in the roots. However, according to the $\mathrm{Ca} / \mathrm{Na}$ in the roots, LYA85 and LYA90 showed the highest ratio under high $\mathrm{F}$ concentration.

Therefore, based on the stability of the tolerance to salinity from germinative to seedlings stage, the commercial variety BOR was identified as the most sensitive to F. BOR showed a high accumulation of $F$ and $\mathrm{Na}$ in $\mathrm{R}$ and $\mathrm{AP}$ with the lowest calcium content under high $\mathrm{KF}$ and $\mathrm{NaF}$ concentration. Among the African bean genotypes, LYA 90 translocated $F$ to shoots thus mimiking the behaviour of a hyperaccumulator. The results indicated that JES and LYA85 were able to accumulate less $\mathrm{Na}$ and $\mathrm{F}$ in 
their $\mathrm{R}$ and AP, altough JES was more susceptible than LYA85. In addition, JES showed a higher reduction in biomass and $\mathrm{R}$ length under high NaF concentration compared to LYA85. However, among the tested genotypes, LYA85 proved to be the most tolerant variety to F exposure.

\section{Discussion}

The effect of $F$ treatment on germination, growth, and $F$ content in plants is still few investigated in the scientific literature. Plant $\mathrm{F}$ tolerance could be associated with several factors such as plant species, genotype and environmental conditions. To the best of our knowledge, this was the first study exploring the bean ( $P$. vulgaris) tolerance to $\mathrm{F}$, taking into account morpho-physiological parameters and the content of $\mathrm{Ca} \mathrm{Na}$ and $\mathrm{K}$ in the biomass during the early stages of growth.

Excess $\mathrm{F}$ in the substrate caused reduced seedlings development and unbalanced nutrient uptake in the four beans genotypes under investigation.

High concentration of $\mathrm{F}\left(200 \mathrm{mg} \mathrm{kg}^{-1}\right)$ deeply altered germination. This behaviour could be associated with the impact of $F$ on plant metabolism. Gadi et al. (2016) reported two possible negative effects of $F$ on plants by i) interfering with active plant metabolism, thus reducing the amylase activity and causing a lower rate of cell division and expansion; and by ii) inducing the gibberellic acid (GA) degradation in seeds deterring the endosperm saccharide metabolism during the germination (Gadi et al. 2016). In this study, partial inhibition of germination was observed in African bean genotypes under KF200, while a stronger effect was observed under NaF200 where even germination was completely inhibited. Similar results about a more toxic effect of $\mathrm{NaF}$ than $\mathrm{KF}$ on bean growth have been reported by Chahine et al. (2021). The higher toxicity of $\mathrm{NaF}$ than $\mathrm{KF}$ could be justified by a possible synergistic effect of $\mathrm{Na}$ and $\mathrm{F}$ together causing the inhibition of vital systems in plants. As already described, NaF causes an inhibitory effect on DNA synthesis in germinating mung bean seeds leading to decreased RNA and protein synthesis, and to reduced cell division and cell elongation (Nitsan and Lang, 1965).

F affected more strongly root growth than the aerial part of the plant. Such a phenomenon may be due to increased absorption of $\mathrm{F}$ by roots as indicated by the total $\mathrm{F}$ content found in roots. Indeed, abnormal seedling development and unbalanced nutrient uptake due to $\mathrm{F}$ interference was reported in another plant species belonged to Leguminosae family, such as Cicer arietinum (Datta et al. 2012).

In plants, $\mathrm{Ca}$ is a ubiquitous secondary messenger involved in multiple signalling cascades in the plant system (Roychoudhury and Banerjee, 2017). Ca content in the root cell walls acts as a buffer against $F$, thus determining plants' $\mathrm{F}$ sensitivity. $\mathrm{F}^{-}$is complexed with $\mathrm{Ca}^{2+}$ present in the root cell walls. Thus, species with high $\mathrm{Ca}$ in the root better control the absorption of $\mathrm{F}^{-}$(Stevens et al. 1998). It could be hypothesised that $\mathrm{F}^{-}$, as an anion, would follow the pathway taken normally by chloride. Due to its high electronegativity, most of $\mathrm{F}$ probably moves extracellularly from roots cell walls, using the apoplastic pathway to the stele, while only a low $\mathrm{F}$ content take the symplastic transport (cell membrane, plasmalemma, or tonoplast) (White and Broadley, 2001). 
Therefore, $\mathrm{F}$ acts as metabolic inhibitor in plants (Iram and Khan 2016). At the molecular level, a large number of Ca transporters, sensor/decoder elements and calcium-dependent transcription factors are known to be regulated by $\mathrm{Ca}$ at different levels either by direct binding of $\mathrm{Ca}$, or calmodulin or by other kinases/phosphatases. $\mathrm{Ca}$ is also essential for K-Na selectivity, markedly reducing $\mathrm{K}$ efflux in saltstressed plants (Munns and Tester, 2008). A high Na/Ca ratio, however, has a deleterious effect on the function of membranes within cells (Cramer et al. 1985) .

Several studies have reported the role of $\mathrm{Ca}$ in salinity stress response, and little information is available about its role as mediator of stress caused by $\mathrm{F}$. The present study showed an opposite trend of $\mathrm{Ca}$ response to $\mathrm{NaCl}$ and $\mathrm{F}$ stresses, which revealed that low $\mathrm{Ca}$ increased the membrane permeability leading to an increase in passive $\mathrm{F}$ and $\mathrm{Na}$ transport. This response became noticeable at high external ion concentrations i.e., NaF compared to KF. In addition, the comparison of the Ca content in both the roots and the aerial part of the four tested bean genotypes indicated that LYA 85 had the lowest reduction of $\mathrm{Ca}$ content under KF80 and $\mathrm{NaF} 80$ compared to the control and at the same time it accumulated the lowest content of $\mathrm{F}$ in its organs, thus indicating that it was more tolerant to $\mathrm{F}$ than the other genotypes.

Our results showed a significant higher $F$ translocation from the $R$ into AP under high concentration of $F$ (KF200) for all the bean genotypes studied. The highest Translocation Factor (TF) was found in LYA90 under KF200. JES appeared to be able to accumulate less F compared to LYA85 and LYA90 under NaF and $\mathrm{KF}$ treatments, since it showed the lowest translocation rate at $80 \mathrm{mg} \mathrm{kg}^{-1}$. BOR, accumulated more $F$ compared to the African bean genotypes. Variable $F$ accumulation in the AP biomass between cultivars had been previously reported. This phenomenon was related to the variable root-shoot translocation efficiency determining $F$ accumulation in AP (Mondal, 2017). Moreover, $F$ accumulation in leaves is mainly in the form of free $\mathrm{F}$ anions, or in connection with aluminium (Al), $\mathrm{Ca}$, and magnesium $(\mathrm{Mg})$ (Weinstein and Davison, 2004).

Ion regulation is an essential factor regulating plant salt tolerance. The studies using $\mathrm{NaCl}$ as the selective agent, revealed the ability of specific plant genotypes to maintain higher levels of $\mathrm{K}$ and $\mathrm{Ca}$ and low levels of $\mathrm{Na}$ and $\mathrm{Cl}$ as one of the key mechanisms contributing to the expression of high salt tolerance. In the screening of plant genotypes for salt tolerance, $\mathrm{K} / \mathrm{Na}$ and $\mathrm{Ca} / \mathrm{Na}$ ratios in the aerial part and tissues $\mathrm{Na}$ concentration have often been proposed as a useful screening tool to determine the salt tolerance of different crop species (Shabala and Cuin, 2008).

High $\mathrm{Na}$ content in the soil solution can inhibit the uptake of other nutrients because $\mathrm{Na}$ interferes with various transporters in the root plasma membrane, such as K-selective ion channels, and constrains root growth (Tester and Davenport, 2003). Although Na transport to AP is largely unidirectional through the xylem, it can only return to roots via the phloem which is a limited process and thus results in progressive accumulation of $\mathrm{Na}$ as leaves age (Tester and Davenport, 2003). The toxic effect of $\mathrm{Na}$ is due to its tendency to replace $\mathrm{K}$ in key enzymes of the cytosol and organelles, and to trigger the accumulation of reactive oxygen species (Munns et al. 2016). High levels of Na may also adversely affect the nutritional 
status of plants by interfering with the absorption of $\mathrm{Ca}$, resulting in $\mathrm{NaCl}$ toxicity in plant tissues caused by low $\mathrm{Ca} / \mathrm{Na}$ ratios (Kent and Lauchli, 1985).

\section{Conclusions}

The soil contamination with F proved to be particularly serious for the salt-sensitive crops that feed many people around the world, like bean. The results obtained in this study provided new evidence on the key physiological responses that underlie $\mathrm{F}$ tolerance in Phaseolus vulgaris at a very early stage of growth. The high sensitivity showed by this crop has compromised plant survival and yield.

In summary, the observed patterns of mineral and morpho-physiological changes in the four bean genotypes exposed to increasing $\mathrm{F}$ concentrations supplied through different salts revealed that

1. the most resistant genotypes, LYA85 and JES, showed a reduced F uptake and translocation from roots to the aerial part,

2. the lowest $F$ content in roots and its sequestration with Ca was shown by LYA85,

3. F contamination affects the mobility of minerals and their translocation to growing organs, which enhanced $\mathrm{Na}$ uptake and reduced $\mathrm{K}$ and $\mathrm{Ca}$ absorption in root and shoot of all the bean genotypes studied,

4. BOR was more sensitive to $F$ toxicity than the other genotypes,

5. F inhibited shoot elongation, and the root system proved to be more sensitive than aerial part to the $F$ stress.

This study has unfolded the central role of $\mathrm{Ca}$, as a key secondary messenger in regulating the plant growth and development under $\mathrm{F}$ stress. High throughput genetic analyses should be performed to identify quantitative traits to be exploited to generate F-tolerant characters in susceptible crops. Further research also is needed to ascertain rates of plant uptake of $\mathrm{F}$ under a wide range of soil $\mathrm{pH}$ values, and the potential impacts of elevated $\mathrm{F}$ levels on microbiological processes such as nitrogen fixation and nitrification.

\section{Declarations}

\section{Acknowledgments}

This study was conducted in the context of the Agreement between the Department of Agricultural Sciences of the University of Sassari and the Faculty of Agricultural Sciences and Veterinary Medicine of the Lebanese University and was funded by EU H2020 FLOWERED project 690378 'de - FLuoridation technologies for imprOving quality of WatEr and agRo - animal products along the East African Rift Valley in the context of aDaptation to climate change'. Authors are grateful to Mario Deroma and Linda Canu for their technical support in the lab.

\section{Author Contributions}


GS, SM, PPR conceived and designed the research; SC, performed the experiments and analysed the data; VG, GS and PPR, analysed the data and revised the manuscript, PPR, GS and SM discussed the data; SC wrote the manuscript with the contributions from the other authors.

\section{Conflicts of Interest}

On behalf of all authors, the corresponding author states that there is no conflict of interest.

\section{References}

1. Aktas H, Abak K, Cakmak I (2006) Genotypic variation in the response of pepper to salinity. Sci Hort 110(3):260-266. https://doi.org/10.1016/j.scienta.2006.07.017

2. Baker AJM (1986) Metal tolerance. New Phytol 106:93-111. https://doi.org/10.1111/j.14698137.1987.tb04685.x

3. Chahine S, Giannini V, Roggero PP, Melito S (2021) First insight of exogenous addition of proline and glycinebetaine to mitigate fluorine toxicity effects on common bean seedlings. Ital J Agron 16(2). https://doi.org/10.4081/ija.2020.1754

4. Choubisa SL, Choubisa D (2016) Status of industrial fluoride pollution and its diverse adverse health effects in man and domestic animals in India. Environ Sci Pollut Res 23(8):7244-7254. https://doi.org/10.1007/s11356-016-6319-8

5. Cramer GR, Läuchli A, Polito VS (1985) Displacement of Ca $2+$ by $\mathrm{Na}+$ from the Plasmalemma of Root Cells. Plant Physiol 79(1):207-211. https://doi.org/10.1007/s11356-016-6319-8

6. Cronin SJ, Neall VE, Lecointre JA, Hedley MJ, Loganathan P (2003) Environmental hazards of Fuoride in volcanic ash: a case study from Ruapehu volcano. New Zealand J Volcanol Geotherm Res 121(3-4):271-291. https://doi.org/10.1016/S0377-0273(02)00465-1

7. Datta J, Maitra A, Mondal N, Banerjee A (2012) Studies on the impact of fluoride toxicity on germination and seedling growth of gram seed (Cicer arietinum L. cv. Anuradha). J Stress Physiol Biochem 8(1):194-202

8. Dey U, Mondal NK, Das K, Datta JK (2012) Dual effects of fluoride and calcium on the uptake of fluoride, growth physiology, pigmentation, and biochemistry of Bengal Gram seedlings (Cicer arietinum L.). Fluoride 45(4):389-393

9. Elloumi N, Ben Abdallah F, Mezghani I, Rhouma A, Boukhris M (2005) Effect of flouride on almond seedlings in culture solution. Fluoride 38(3):193-198

10. FAOSTAT (2014) Food and Agriculture Organization. of the United Nations

11. Fornasiero RB (2003) Fluorides effects on Hypericum perforatum plants: First field observations. Plant Sci 165(3):507-513. https://doi.org/10.1016/S0168-9452(03)00205-X

12. Frencken J (1992) Endemic fluorosis in developing countries: causes, effects and possible solutions. Publication no.91.082. NIPG-TNO, Leiden ed. 
13. Gadi BR, Bhati K, Goswami B, Rankawat R, Kumar S, Kumar R, Ram A, Pooja V, Laxmi V, Singariya P (2016) Sources and phytotoxicity of fluorides in the environment. In: Bamniya BR, Gadi BR (eds) Environmental Impact on Biodiversity. Today \& Tomorrow's Printers and Publishers, New Delhi, pp 251-266

14. Galkovskyi T, Mileyko Y, Bucksch A, Moore B, Symonova O, Price CA, Topp CN, lyer-Pascuzzi AS, Zurek PR, Fang S, Harer J, Benfey PN, Weitz JS (2012) GiA Roots: Software for the high throughput analysis of plant root system architecture. BMC Plant Biol 12: 116. http://www.biomedcentral.com/1471-2229/12/116

15. George F, Ramachandran KM (2011) Estimation of parameters of johnson's system of distributions. JMASM 10(2):494-504. DOI:10.22237/jmasm/1320120480

16. Gupta S, Banerjee S, Mondal S (2009) Phytotoxicity of fluoride in the germination of paddy (Oryza sativa) and its effect on the physiology and biochemistry of germinated seedlings. Fluoride 42:142146

17. Iram A, Khan TI (2016) Effect of sodium fluoride on seed germination, seedling growth and biochemistry of Abelmoschus esculentus. J Plant Biochem Physiol 4:170

18. Jha SK, Nayak AK, Sharma YK (2008) Response of spinach (Spinacea oleracea) to the added fluoride in an alkaline soil. Food Chem Toxicol 46:2968-2971. https://doi.org/10.1016/j.fct.2008.05.024

19. Kamaluddin M, Zwiazek JJ (2003) Fluoride inhibits root water transport and affects leaf expansion and gas exchange in aspen (Populus tremuloides) seedlings. Physiol Plant 117(3):368-375. https://doi.org/10.1034/j.1399-3054.2003.00040.x

20. Katungi E, Farrow A, Chianu J, Sperling L, Beebe S (2009) International Centre for Tropical Agriculture: Common bean in Eastern and Southern Africa: a situation and outlook analysis 1-44

21. Kent LM, Lauchli A (1985) Germination and seedling growth of cotton: salinity-calcium interactions. Plant Cell Environ 8(2):155-159. doi:10.1111/j.1365-3040.1985.tb01223.x

22. Loganathan P, Hedley MJ, Grace ND, Lee J, Cronin SJ, Bolan NS, Zanders JM (2003) Fertiliser contaminants in New Zealand grazed pasture with special reference to cadmium and fluorine - a review AJSR 41(3): 501-532. https:// doi.org/10.1071/SR02126

23. Maggio A, Reddy MP, Joly RJ (2000) Leaf gas exchange and solute accumulation in the halophyte Salvadora persica grown at moderate salinity. Environ Exp Bot 44(1):31-38. https://doi.org/10.1016/S0098-8472(00)00051-4

24. Mondal NK (2017) Effect of fluoride on photosynthesis, growth and accumulation of four widely cultivated rice (Oryza sativa L.) varieties in India. Ecotoxicol Environ Saf 144:36-44. https://doi.org/10.1016/j.ecoenv.2017.06.009

25. Munns R, James RA. Gilliham M, Flowers TJ, Colmer TD (2016) Tissue tolerance: an essential but elusive trait for salt-tolerant crops. Funct Plant Biol 43(12):1103-1113. https://doi.org/10.1071/FP16187

26. Munns R, Tester M (2008) Mechanisms of Salinity Tolerance. Annu Rev Plant Biol 59:651-681. https://doi.org/10.1146/annurev.arplant.59.032607.092911 
27. Nitsan J, Lang A (1965) Inhibition of cell division and cell elongation in higher plants by inhibitors of DNA synthesis. Dev Biol 12(3):358-376. https://doi.org/10.1016/0012-1606(65)90003-5

28. Rizzu M, Tanda A, Canu L, Masawe K, Mtei K, Deroma MA, Roggero PP, Seddaiu G (2020) Fluoride uptake and translocation in food crops grown in fluoride-rich soils. J Sci Food Agric 100(15):54985509. https://doi.org/10.1002/jsfa.10601

29. Roychoudhury A, Banerjee $A$ (2017) Abscisic acid signaling and involvement of mitogen activated protein kinases and calcium-dependent protein kinases during plant abiotic stress. Mechanism of plant hormone signaling under stress 1:197-241

30. Shabala S, Cuin TA (2008) Potassium transport and plant salt tolerance. Physiol Plant 133(4):651669. https://doi.org/10.1111/j.1399-3054.2007.01008.x

31. Stevens DP, Mclaughlin MJ, Alston AM (1998) Phytotoxicity of the fluoride ion and its uptake from solution culture by Avena sativa and Lycopersicon esculentum. Plant Soil 200(2): 119-129

32. Tester M, Davenport R (2003) Na + Tolerance and $\mathrm{Na}+$ Transport in Higher Plants. Ann Bot 91:503527

33. Weinstein H, Davison A (2004) Uptake, transport and accumulation of inorganic fluorides by plants and animals. In: Fluorides in the Environment on plants and animals. CABI Publishing, pp 21-55. DOI:10.1079/9780851996837.0021

34. White PJ, Broadley MR (2001) Chloride in Soils and its Uptake and Movement within the Plant: a review. Ann Bot 88(6):967-988. https://doi.org/10.1006/anbo.2001.1540

35. WHO (1984) Fluorine and fluorides. Environmental Health Criteria

\section{Tables}

Table 1 Effect of different salt on bean germination.Germination (\%) of bean genotypes: Borlotto (BOR), Jesca (JES), Lyamunguru 85 (LYA85) and Lyamunguru 90 (LYA90). In table are reported the results for control condition (F0), and for treatments with different salts (KF, NaF and $\mathrm{NaCl}$ ) at two different concentrations ( 80 and $200 \mathrm{mg} \mathrm{kg}^{-1}$ ). Different letters indicate significant differences at $p<0.01$ according to the Tukey post-hoc test based on each genotype 


\begin{tabular}{lllll} 
Treatment & \multicolumn{3}{l}{ Genotype } \\
\cline { 2 - 5 }$\left(\mathrm{mg} \mathrm{kg}^{-1}\right)$ & BOR & JES & LYA85 & LYA90 \\
\hline F0 & $100^{\mathrm{a}}$ & $100^{\mathrm{a}}$ & $100^{\mathrm{a}}$ & $100^{\mathrm{a}}$ \\
\hline $\mathrm{KF80}$ & $79^{\mathrm{d}}$ & $93^{\mathrm{b}}$ & $69^{\mathrm{b}}$ & $83^{\mathrm{c}}$ \\
\hline $\mathrm{KF} 200$ & $0^{\mathrm{e}}$ & $10^{\mathrm{d}}$ & $7^{\mathrm{C}}$ & $28^{\mathrm{d}}$ \\
\hline $\mathrm{NaF} 80$ & $86^{\mathrm{C}}$ & $83^{\mathrm{C}}$ & $100^{\mathrm{a}}$ & $90^{\mathrm{b}}$ \\
\hline $\mathrm{NaF} 200$ & $0^{\mathrm{e}}$ & $0^{\mathrm{e}}$ & $0^{\mathrm{d}}$ & $0^{\mathrm{e}}$ \\
\hline $\mathrm{NaCl} 80$ & $93^{\mathrm{b}}$ & $93^{\mathrm{b}}$ & $100^{\mathrm{a}}$ & $100^{\mathrm{a}}$ \\
\hline $\mathrm{NaCl} 200$ & $93^{\mathrm{b}}$ & $93^{\mathrm{b}}$ & $100^{\mathrm{a}}$ & $100^{\mathrm{a}}$
\end{tabular}

Table 2 Effect of different salts ( $\mathrm{KF}, \mathrm{NaF}$ and $\mathrm{NaCl}$ ) at two different concentrations (80 and $200 \mathrm{mg} \mathrm{kg}^{-1}$ ) on growth ratio \% (GR\%) and tolerance index (TI) in 4 bean varieties: Borlotto, Jesca, Lyamunguru 85 , Lyamunguru 90 (BOR, JES, LYA85 and LYA90, respectively). GR\% and TI were calculated according to Eq 2 and 3 (see material and methods). Data are compared to the control ( $F 0)$ results ( $\mathrm{TI}=1, \mathrm{GR}=100 \%$ ). Different lowercase letters indicate significant differences at $p<0.01$ according to the Tukey post-hoc test based on treatment within each genotype. Different capital letters indicate significant differences at $p$ $<0.01$ according to the Tukey post-hoc test based on genotype within each treatment. 


\begin{tabular}{|c|c|c|c|}
\hline Genotype & $\begin{array}{l}\text { Treatment } \\
\mathrm{mg} \mathrm{kg}^{-1}\end{array}$ & $\mathrm{TI}$ & GR\% \\
\hline \multirow[t]{7}{*}{ BOR } & F0 & $1.00 \pm 0.00 \mathrm{Aa}$ & $100.00 \pm 0.00$ \\
\hline & KF80 & $0.72 \pm 0.01^{\mathrm{De}}$ & $91.08 \pm 0.11^{\mathrm{Bc}}$ \\
\hline & KF200 & $N A^{*}$ & $N A^{*}$ \\
\hline & NaF80 & $0.76 \pm 0.00^{B d}$ & $84.01 \pm 0.37^{\mathrm{Ad}}$ \\
\hline & $\mathrm{NaF} 200$ & $N A^{*}$ & $N A^{*}$ \\
\hline & $\mathrm{NaCl} 80$ & $0.96 \pm 0.01^{\mathrm{Bb}}$ & $99.32 \pm 0.29 \mathrm{Aa}$ \\
\hline & $\mathrm{NaCl} 200$ & $0.88 \pm 0.01^{\mathrm{Cc}}$ & $95.05 \pm 0.73^{A b}$ \\
\hline \multirow[t]{7}{*}{ JES } & F0 & $1.00 \pm 0.00 \mathrm{Aa}$ & $100.00 \pm 0.00 \mathrm{Aa}$ \\
\hline & KF80 & $0.82 \pm 0.01^{\mathrm{Cc}}$ & $75.66 \pm 1.34 \mathrm{Ca}$ \\
\hline & KF200 & $0.52 \pm 0.04 \mathrm{Ae}$ & $80.39 \pm 20.74$ \\
\hline & $\mathrm{NaF} 80$ & $0.62 \pm 0.00^{C d}$ & $47.91 \pm 0.95^{\mathrm{Db}}$ \\
\hline & NaF200 & $N A^{*}$ & $N A^{*}$ \\
\hline & $\mathrm{NaCl} 80$ & $1.00 \pm 0.01 \mathrm{Aa}$ & $78.73 \pm 0.39 \mathrm{Ca}$ \\
\hline & $\mathrm{NaCl} 200$ & $0.90 \pm 0.01^{\mathrm{BCb}}$ & $73.87 \pm 0.20 \mathrm{Cab}$ \\
\hline \multirow[t]{7}{*}{ LYA85 } & F0 & $1.00 \pm 0.00 \mathrm{Aa}$ & $100.00 \pm 0.00$ \\
\hline & KF80 & $0.92 \pm 0.00^{\mathrm{Ba}}$ & $95.42 \pm 0.74 \mathrm{Aa}$ \\
\hline & KF200 & $0.49 \pm 0.11^{\mathrm{Ac}}$ & $77.64 \pm 19.25^{A b}$ \\
\hline & NaF80 & $0.77 \pm 0.00^{\mathrm{Bb}}$ & $58.95 \pm 0.06^{\mathrm{Cc}}$ \\
\hline & $\mathrm{NaF} 200$ & $N A^{*}$ & $N A^{*}$ \\
\hline & $\mathrm{NaCl} 80$ & $0.92 \pm 0.01^{\mathrm{Ba}}$ & $102.54 \pm 1.85$ \\
\hline & $\mathrm{NaCl} 200$ & $0.92 \pm 0.01^{\mathrm{Ba}}$ & $88.71 \pm 1.14^{\mathrm{Bab}}$ \\
\hline \multirow[t]{3}{*}{ LYA90 } & F0 & $1.00 \pm 0.00 \mathrm{Ac}$ & $100.00 \pm 0.00$ \\
\hline & KF80 & $1.04 \pm 0.01^{\mathrm{Ab}}$ & $75.67 \pm 0.58 \mathrm{Cc}$ \\
\hline & KF200 & $0.67 \pm 0.02^{\mathrm{Ae}}$ & $61.52 \pm 1.32 \mathrm{Ae}$ \\
\hline
\end{tabular}




\begin{tabular}{|c|c|c|c|}
\hline & $\mathrm{NaF} 80$ & $0.94 \pm 0.00 \mathrm{Ad}$ & $71.96 \pm 0.47^{B d}$ \\
\hline & NaF200 & $N A^{*}$ & $N A^{*}$ \\
\hline & $\mathrm{NaCl} 80$ & $1.01 \pm 0.01 \mathrm{Ac}$ & $87.96 \pm 0.95^{\mathrm{Bb}}$ \\
\hline & $\mathrm{NaCl} 200$ & $1.22 \pm 0.00^{\mathrm{Aa}}$ & $85.56 \pm 0.76^{\mathrm{Bb}}$ \\
\hline \multicolumn{4}{|c|}{ Probability level of significance (ANOVA) } \\
\hline \multicolumn{2}{|l|}{ Genotype (A) } & * & $\star *$ \\
\hline \multicolumn{2}{|l|}{ Treatment (B) } & $\star \star \star ~$ & $\star \star \star$ \\
\hline \multicolumn{2}{|l|}{$A * B$} & 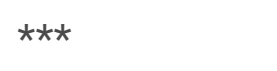 & $\star \star \star *$ \\
\hline
\end{tabular}

*NA: not available plants

Table 3 Effect of different salts ( $\mathrm{KF}, \mathrm{NaF}$ and $\mathrm{NaCl}$ ) at two different concentrations (80 and $200 \mathrm{mg} \mathrm{kg}^{-1}$ ) on dry weight (DW) of aerial part (DW-AP), root (DW-R) and their ratio (R/AP) on 4 bean varieties: Borlotto, Jesca, Lyamunguru 85, Lyamunguru 90 (BOR, JES, LYA85 and LYA90, respectively) and the salt levels: control (F0), 80 and $200 \mathrm{ppm}$. In the table data are reported as means and coefficient of variation. Different lowercase letters indicate significant differences at $p<0.01$ according to Tukey post hoc test among treatments levels within each genotype; Different capital letters indicate significant differences at $p<0.01$ according to the Tukey post-hoc test based on genotype within each treatment.

*NA: not available plants

Table $4 \mathrm{~F}(\mathrm{ppm})$ content in aerial part (F-AP) and root (F-R) of BOR, JES, LYA85 and LYA90 (Borlotto, Jesca, Lyamunguru 85, Lyamunguru 90) treated with KF and NaF at 80-200 $\mathrm{mg} \mathrm{kg}^{-1}$. In table are reported also the control treatment, without fluorine (F0). Data are expressed as average value (coefficient of variation). Different lowercase letters indicate significant differences at $\mathrm{p}<0.01$ according to Tukey post hoc test among genotypes within treatment. Different capital letters indicate significant differences at $p<0.01$ according to the Tukey post-hoc test comparing different treatment within genotype. 
$\begin{array}{llll}\text { Variety Treatment } & \text { DW_AP } & \text { DW_R } & \text { R/AP }\end{array}$ $\mathrm{mg} \mathrm{kg}^{-1}$

\begin{tabular}{|c|c|c|c|c|}
\hline \multirow[t]{7}{*}{ BOR } & F0 & $0.22 \pm 0.00^{A c}$ & $0.17 \pm 0.00^{\mathrm{Ca}}$ & $0.78 \pm 0.00^{\mathrm{Ca}}$ \\
\hline & KF80 & $0.25 \pm 0.00^{\mathrm{Aa}}$ & $0.10 \pm 0.00^{\mathrm{Bc}}$ & $0.40 \pm 0.00^{\mathrm{Cc}}$ \\
\hline & KF200 & $N A^{*}$ & $N A^{*}$ & $N A^{*}$ \\
\hline & NaF80 & $0.24 \pm 0.00^{\mathrm{Ab}}$ & $0.08 \pm 0.00^{\mathrm{Bd}}$ & $0.35 \pm 0.00^{\mathrm{Cd}}$ \\
\hline & NaF200 & $N A^{*}$ & $N A^{*}$ & $N A^{*}$ \\
\hline & $\mathrm{NaCl} 80$ & $0.21 \pm 0.00^{\mathrm{Ad}}$ & $0.17 \pm 0.00^{\mathrm{Ca}}$ & $0.79 \pm 0.01^{\mathrm{Ca}}$ \\
\hline & $\mathrm{NaCl} 200$ & $0.24 \pm 0.00^{\mathrm{Ab}}$ & $0.13 \pm 0.00^{\mathrm{Cb}}$ & $0.55 \pm 0.01^{\mathrm{cb}}$ \\
\hline \multirow[t]{7}{*}{ JES } & F0 & $0.21 \pm 0.00^{\mathrm{Bb}}$ & $0.30 \pm 0.01^{\mathrm{Aa}}$ & $1.47 \pm 0.01^{\mathrm{Aa}}$ \\
\hline & KF80 & $0.20 \pm 0.00^{\mathrm{Bb}}$ & $0.18 \pm 0.01^{\text {Aabc }}$ & $0.92 \pm 0.02^{\mathrm{Bb}}$ \\
\hline & KF200 & $0.26 \pm 0.00^{\mathrm{Aa}}$ & $0.15 \pm 0.10^{\mathrm{Abc}}$ & $0.59 \pm 0.40^{\mathrm{Abc}}$ \\
\hline & $\mathrm{NaF} 80$ & $0.18 \pm 0.00^{C d}$ & $0.06 \pm 0.00^{\mathrm{Dc}}$ & $0.35 \pm 0.01^{\mathrm{Cc}}$ \\
\hline & NaF200 & $N A^{*}$ & $\mathrm{NA}^{*}$ & $N A^{*}$ \\
\hline & $\mathrm{NaCl} 80$ & $0.19 \pm 0.00^{\mathrm{Bc}}$ & $0.21 \pm 0.00^{\mathrm{Bab}}$ & $1.05 \pm 0.01^{\mathrm{Bab}}$ \\
\hline & $\mathrm{NaCl} 200$ & $0.20 \pm 0.00^{\mathrm{Bb}}$ & $0.17 \pm 0.00^{\mathrm{Bbc}}$ & $0.83 \pm 0.01^{\mathrm{Bbc}}$ \\
\hline \multirow[t]{6}{*}{ LYA85 } & F0 & $0.17 \pm 0.00^{\mathrm{Cb}}$ & $0.23 \pm 0.00^{\mathrm{Ba}}$ & $1.33 \pm 0.02^{\mathrm{Ba}}$ \\
\hline & KF80 & $0.19 \pm 0.00^{\mathrm{Cb}}$ & $0.19 \pm 0.00^{\mathrm{Ab}}$ & $1.02 \pm 0.03^{\mathrm{Ac}}$ \\
\hline & KF200 & $0.25 \pm 0.07^{\mathrm{Aa}}$ & $0.05 \pm 0.01^{\mathrm{Ae}}$ & $0.22 \pm 0.04^{\mathrm{Af}}$ \\
\hline & NaF80 & $0.16 \pm 0.00^{\mathrm{Db}}$ & $0.07 \pm 0.00^{\mathrm{Cd}}$ & $0.44 \pm 0.00^{\mathrm{Be}}$ \\
\hline & $\mathrm{NaCl} 80$ & $0.19 \pm 0.00^{\mathrm{Cb}}$ & $0.22 \pm 0.01^{\mathrm{Ba}}$ & $1.19 \pm 0.03^{\mathrm{Ab}}$ \\
\hline & $\mathrm{NaCl} 200$ & $0.18 \pm 0.00^{A b}$ & $0.17 \pm 0.00^{\mathrm{Ac}}$ & $0.91 \pm 0.01^{\mathrm{Ad}}$ \\
\hline \multirow[t]{4}{*}{ LYA90 } & F0 & $0.21 \pm 0.00^{\mathrm{ABb}}$ & $0.30 \pm 0.01^{\mathrm{Aa}}$ & $1.43 \pm 0.04^{\mathrm{Aba}}$ \\
\hline & KF80 & $0.21 \pm 0.00^{\mathrm{Bb}}$ & $0.18 \pm 0.00^{\mathrm{Ad}}$ & $0.88 \pm 0.02^{\mathrm{Bc}}$ \\
\hline & KF200 & $0.23 \pm 0.01^{\mathrm{Aa}}$ & $0.08 \pm 0.00^{\mathrm{Af}}$ & $0.35 \pm 0.01^{\mathrm{Ae}}$ \\
\hline & $\mathrm{NaF} 80$ & $0.21 \pm 0.00^{\mathrm{Ab}}$ & $0.16 \pm 0.00^{\mathrm{Ae}}$ & $0.75 \pm 0.01^{\mathrm{Ad}}$ \\
\hline
\end{tabular}




\begin{tabular}{llll}
$\mathrm{NaF200}$ & $\mathrm{NA}^{*}$ & $\mathrm{NA}^{*}$ & $\mathrm{NA}^{*}$ \\
\hline $\mathrm{NaCl} 80$ & $0.21 \pm 0.00^{\mathrm{Cb}}$ & $0.24 \pm 0.00^{\mathrm{Bb}}$ & $1.13 \pm 0.01^{\mathrm{Ab}}$ \\
\hline $\mathrm{NaCl} 200$ & $0.23 \pm 0.00^{\mathrm{Aa}}$ & $0.21 \pm 0.00^{\mathrm{Ac}}$ & $0.90 \pm 0.00^{\mathrm{Ac}}$
\end{tabular}

Probability level of significance (ANOVA)

\begin{tabular}{|c|c|c|c|}
\hline Genotype (A) & $\star \star \star \star$ & n.s. & * \\
\hline Treatment (B) & $\star \star \star *$ & $\star \star \star *$ & $\star \star \star \star ~$ \\
\hline$A^{\star} B$ & $\star \star \star *$ & $\star \star \star$ & $\star \star \star *$ \\
\hline Coefficient of Variation & $15 \%$ & $49 \%$ & $50 \%$ \\
\hline
\end{tabular}


Treatment Genotypes $\quad F(A P) \quad F(R)$

$\mathrm{mg} \mathrm{kg}^{-1}$

\begin{tabular}{|c|c|c|c|}
\hline \multirow[t]{4}{*}{ FO } & BOR & $4.08 \pm 1.19^{\mathrm{Cb}}$ & $6.75 \pm 0,59^{\mathrm{Ba}}$ \\
\hline & JES & $2.40 \pm 0.17^{\mathrm{Db}}$ & $4.02 \pm 0.28^{\mathrm{Cb}}$ \\
\hline & LYA85 & $4.17 \pm 0.52^{\mathrm{Bb}}$ & $3.08 \pm 0.58^{\mathrm{Bb}}$ \\
\hline & LYA90 & $8.15 \pm 0.30^{\mathrm{Ca}}$ & $4.81 \pm 0.13^{\mathrm{Cab}}$ \\
\hline \multirow[t]{4}{*}{ KF80 } & BOR & $18.52 \pm 1.35^{\mathrm{B}}$ & $31.98 \pm 6.13^{\mathrm{A}}$ \\
\hline & JES & $15.90 \pm 0.35^{C}$ & $25.06 \pm 0.02^{B}$ \\
\hline & LYA85 & $9.83 \pm 0.31^{\mathrm{B}}$ & $16.93 \pm 2.38^{B}$ \\
\hline & LYA90 & $14.27 \pm 3.62^{\mathrm{BC}}$ & $17.50 \pm 6.78^{\mathrm{BC}}$ \\
\hline \multirow[t]{4}{*}{ KF200 } & BOR & NA & NA \\
\hline & JES & $75.70 \pm 3.42^{A b}$ & $47.63 \pm 2.15^{\mathrm{Ab}}$ \\
\hline & LYA85 & $100.11 \pm 11.57^{\text {Aab }}$ & $65.31 \pm 7.55^{\mathrm{Aa}}$ \\
\hline & LYA90 & $115.44 \pm 0.54^{\mathrm{Aa}}$ & $37.60 \pm 0.26^{A b}$ \\
\hline \multirow[t]{5}{*}{ NaF80 } & BOR & $37.21 \pm 3.20^{\mathrm{Aa}}$ & $29.93 \pm 4.33^{A b}$ \\
\hline & JES & $27.93 \pm 1.25^{\mathrm{Bab}}$ & $43.41 \pm 1.94^{\mathrm{Aa}}$ \\
\hline & LYA85 & $17.67 \pm 3.07^{\mathrm{Bb}}$ & $10.98 \pm 2.08^{\mathrm{Bc}}$ \\
\hline & LYA90 & $21.25 \pm 1.88^{\mathrm{Bb}}$ & $25.17 \pm 2.08^{A b b}$ \\
\hline & BOR & NA & NA \\
\hline \multirow[t]{3}{*}{ NaF200 } & JES & NA & NA \\
\hline & LYA85 & NA & NA \\
\hline & LYA90 & NA & NA \\
\hline
\end{tabular}

Probability level of significance (ANOVA)

\begin{tabular}{lll} 
Genotype (A) & NsS & NS \\
\hline Treatment (B) & $* \star *$ & $* \star *$ \\
\hline A*B & $* * *$ & $* \star *$ \\
Coefficient of Variation & $\begin{array}{c}114 \% \\
\text { Page } 20 / 25\end{array}$ & $74 \%$ \\
\hline
\end{tabular}


NA: not available plants

NS: non-significant

Table 5 Root (R) and aerial part (AP) K/Na and $\mathrm{Ca} / \mathrm{Na}(\mathrm{K} / \mathrm{Na}(\mathrm{R})-\mathrm{K} / \mathrm{Na}(\mathrm{AP})-\mathrm{Ca} / \mathrm{Na}(\mathrm{R})-\mathrm{Ca} / \mathrm{Na}(\mathrm{AP})$ ) ratios of the bean genotypes studied (Borlotto, Jesca, Lyamunguru 85, Lyamunguru 90 (BOR, JES, LYA85 and LYA90, respectively) grown in $\mathrm{KF}, \mathrm{NaF}$ and $\mathrm{NaCl}$ sand without (F0) and with $\mathrm{F}$ (80 and $200 \mathrm{mg} \mathrm{kg}^{-1}$ ). Different letters indicate significant differences at $p<0.01$ according to Tukey post hoc test among genotypes within treatment. 


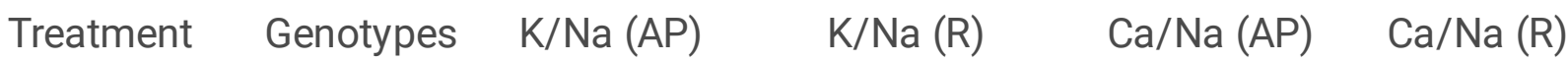
$\mathrm{mg} \mathrm{kg}^{-1}$

\begin{tabular}{|c|c|c|c|c|c|}
\hline \multirow[t]{4}{*}{ Fo } & BOR & $51.49 \pm 0.64^{b}$ & $1.97 \pm 0.00^{\mathrm{a}}$ & $7.11 \pm 0.14^{\mathrm{ab}}$ & $0.77 \pm 0.00^{c}$ \\
\hline & JES & $89.68 \pm 10.25^{a}$ & $1.60 \pm 0.05^{c}$ & $8.66 \pm 1.03^{a}$ & $0.81 \pm 0.01^{b}$ \\
\hline & LYA85 & $53.84 \pm 1.78^{b}$ & $1.80 \pm 0.03^{b}$ & $7.99 \pm 0.23^{a}$ & $0.77 \pm 0.00^{c}$ \\
\hline & LYA90 & $45.90 \pm 1.20^{\mathrm{b}}$ & $1.41 \pm 0.04^{d}$ & $6.02 \pm 0.06^{b}$ & $0.86 \pm 0.02^{a}$ \\
\hline \multirow[t]{4}{*}{ KF80 } & BOR & $104.88 \pm 5.11^{b}$ & $1.85 \pm 0.12^{\mathrm{C}}$ & $8.04 \pm 0.58^{a}$ & $0.31 \pm 0.02^{b}$ \\
\hline & JES & $140.30 \pm 8.94^{a}$ & $2.67 \pm 0.04^{b}$ & $8.52 \pm 0.62^{a}$ & $0.68 \pm 0.04^{a}$ \\
\hline & LYA85 & $58.04 \pm 1.79^{c}$ & $3.44 \pm 0.01^{a}$ & $5.84 \pm 0.14^{b}$ & $0.76 \pm 0.00^{a}$ \\
\hline & LYA90 & $64.66 \pm 0.33^{c}$ & $2.82 \pm 0.24^{b}$ & $5.05 \pm 0.05^{b}$ & $0.75 \pm 0.03^{a}$ \\
\hline \multirow[t]{4}{*}{ KF200 } & BOR & NA & NA & NA & NA \\
\hline & JES & $52.00 \pm 0.00^{a}$ & $3.17 \pm 0.00^{\mathrm{a}}$ & $1.40 \pm 0.00^{b}$ & $0.08 \pm 0.00^{b}$ \\
\hline & LYA85 & $32.56 \pm 0.00^{c}$ & $1.73 \pm 0.06^{b}$ & $0.88 \pm 0.00^{c}$ & $0.35 \pm 0.02^{a}$ \\
\hline & LYA90 & $43.61 \pm 1.39^{b}$ & $1.41 \pm 0.05^{c}$ & $1.64 \pm 0.08^{a}$ & $0.35 \pm 0.02^{a}$ \\
\hline \multirow[t]{5}{*}{ NaF80 } & BOR & $18.21 \pm 2.20^{a}$ & $0.27 \pm 0.01^{a b}$ & $1.40 \pm 0.20^{\mathrm{a}}$ & $0.11 \pm 0.01^{\mathrm{b}}$ \\
\hline & JES & $16.16 \pm 0.54^{a}$ & $0.15 \pm 0.01^{c}$ & $1.25 \pm 0.00^{a}$ & $0.09 \pm 0.00^{b}$ \\
\hline & LYA85 & $17.02 \pm 1.47^{a}$ & $0.24 \pm 0.01^{b}$ & $1.57 \pm 0.29^{a}$ & $0.15 \pm 0.01^{a}$ \\
\hline & LYA90 & $15.74 \pm 0.51^{a}$ & $0.29 \pm 0.1^{a}$ & $1.04 \pm 0.07^{a}$ & $0.17 \pm 0.01^{a}$ \\
\hline & BOR & NA & NA & NA & NA \\
\hline \multirow[t]{3}{*}{ NaF200 } & JES & NA & NA & NA & NA \\
\hline & LYA85 & NA & NA & NA & NA \\
\hline & LYA90 & NA & NA & NA & NA \\
\hline \multirow[t]{4}{*}{$\mathrm{NaCl} 80$} & BOR & $28.17 \pm 0.68^{a}$ & $0.45 \pm 0.00^{b}$ & $4.97 \pm 0.10^{\mathrm{a}}$ & $0.36 \pm 0.00^{d}$ \\
\hline & JES & $21.36 \pm 0.21^{c}$ & $0.40 \pm 0.00^{c}$ & $3.87 \pm 0.02^{b}$ & $0.46 \pm 0.00^{c}$ \\
\hline & LYA85 & $16.10 \pm 0.58^{d}$ & $0.63 \pm 0.01^{a}$ & $3.24 \pm 0.16^{c}$ & $0.58 \pm 0.01^{b}$ \\
\hline & LYA90 & $25.40 \pm 0.23^{b}$ & $0.47 \pm 0.02^{b}$ & $4.96 \pm 0.05^{a}$ & $0.67 \pm 0.00^{a}$ \\
\hline
\end{tabular}




\begin{tabular}{|c|c|c|c|c|c|}
\hline \multirow[t]{4}{*}{$\mathrm{NaCl} 200$} & BOR & $9.22 \pm 0.04^{b}$ & $0.22 \pm 0.00^{d}$ & $1.83 \pm 0.03^{b}$ & $0.38 \pm 0.00^{a}$ \\
\hline & JES & $13.09 \pm 0.84^{a}$ & $0.25 \pm 0.00^{c}$ & $2.77 \pm 0.19^{a}$ & $0.37 \pm 0.00^{a}$ \\
\hline & LYA85 & $6.71 \pm 0.37^{c}$ & $0.31 \pm 0.00^{a}$ & $1.45 \pm 0.08^{c}$ & $0.35 \pm 0.01^{b}$ \\
\hline & LYA90 & $8.68 \pm 0.18^{b}$ & $0.27 \pm 0.00^{b}$ & $1.83 \pm 0.02^{b}$ & $0.22 \pm 0.00^{c}$ \\
\hline
\end{tabular}

Probability level of significance (ANOVA)

\begin{tabular}{lllll} 
Genotype $(A)$ & n.s. & n.s. & n.s. & n.s. \\
\hline Treatment $(B)$ & $\star \star \star$ & $\star \star \star$ & $\star \star \star$ & $\star \star \star$ \\
\hline$A^{\star B}$ & $\star \star \star$ & $\star \star \star$ & $\star \star \star$ & $\star \star \star$ \\
\hline Coefficient of Variation & $32 \%$ & $19 \%$ & $21 \%$ & $19 \%$
\end{tabular}

\section{Figures}

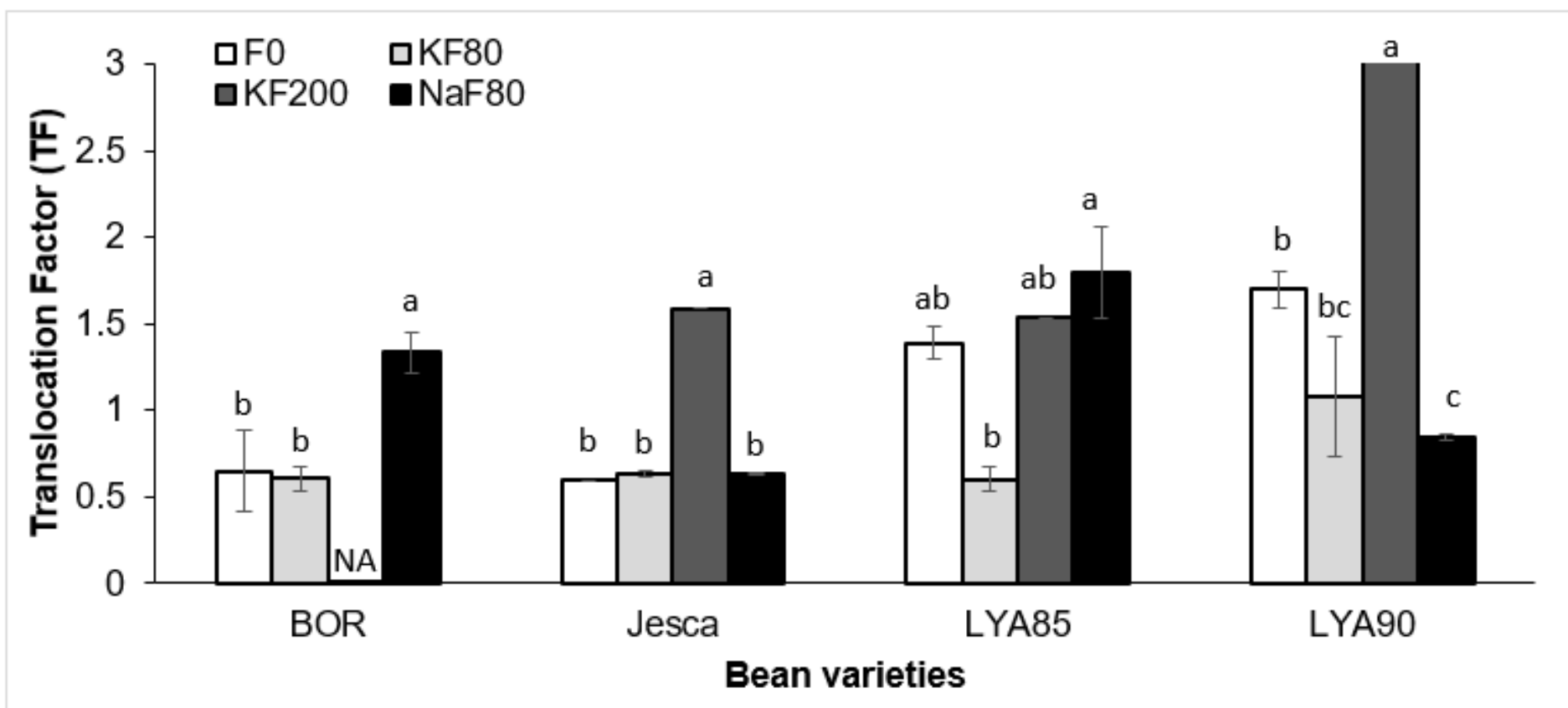

Figure 1

Translocation factor (TF) of four bean ecotypes (BOR, JES, LYA85 and LYA90) under different sources of $\mathrm{F}$ (KF and NaF 80 and $200 \mathrm{mg} \mathrm{kg-1).} \mathrm{TF} \mathrm{was} \mathrm{evaluated} \mathrm{according} \mathrm{to} \mathrm{Eq.4} \mathrm{(see} \mathrm{material} \mathrm{and} \mathrm{methods).}$ Vertical bars represent standard error. Different letters indicate significant differences at $p<0.01$ according to the Tukey post-hoc test based on treatments within genotype. NA: Not Available Data 

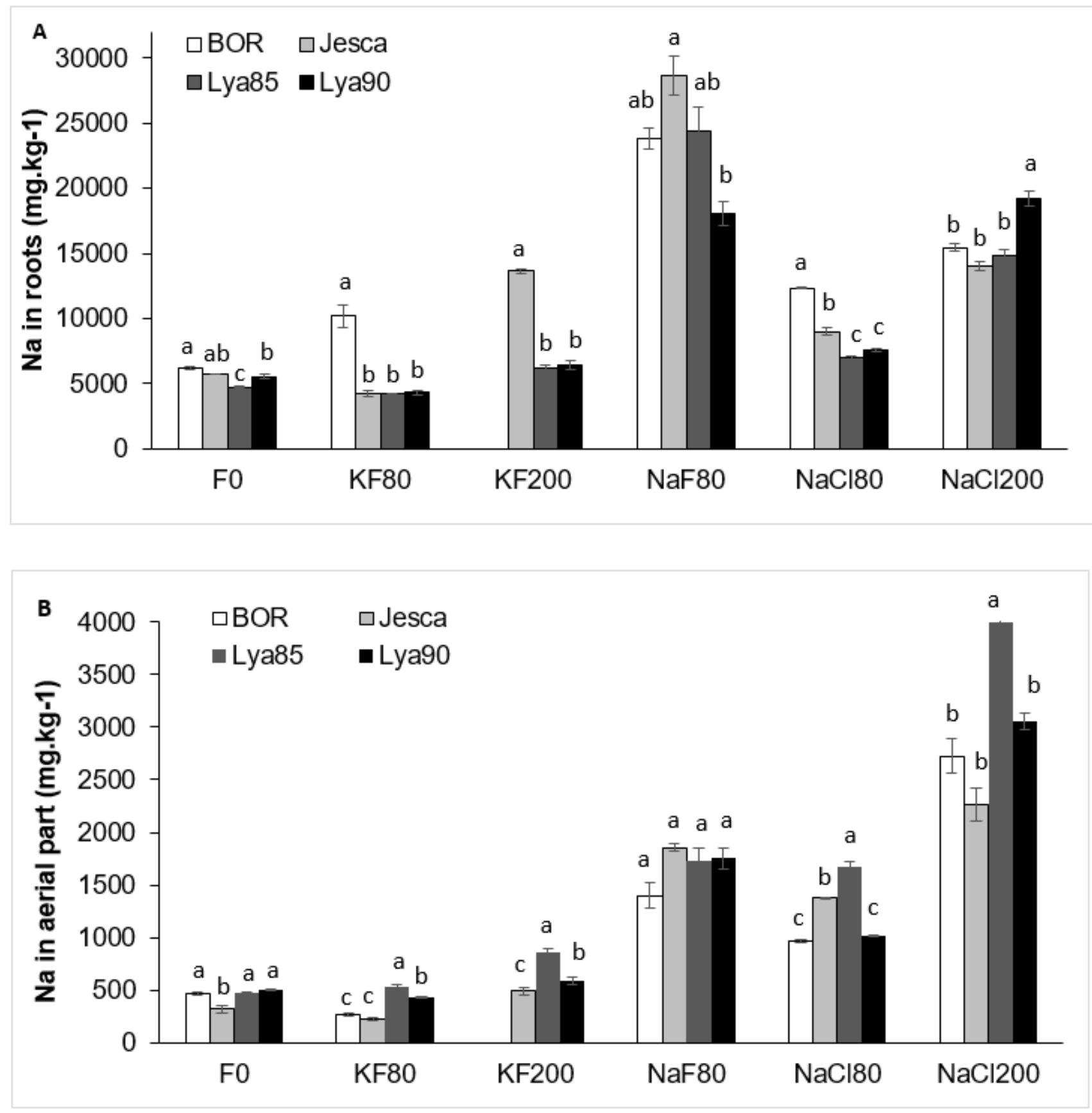

Figure 2

Effect of $\mathrm{KF}, \mathrm{NaF}$, and $\mathrm{NaCl}$ treatments on the accumulation of $\mathrm{Na}+(\mathrm{mg} \mathrm{kg}-1)$ in aerial part (AP) (A) and root $(R)(B)$ of the four tested bean genotypes. Standard errors are shown as vertical bars. Different letters indicate significant differences at $p<0.01$ according to Tukey post hoc test among genotypes within each treatment. 

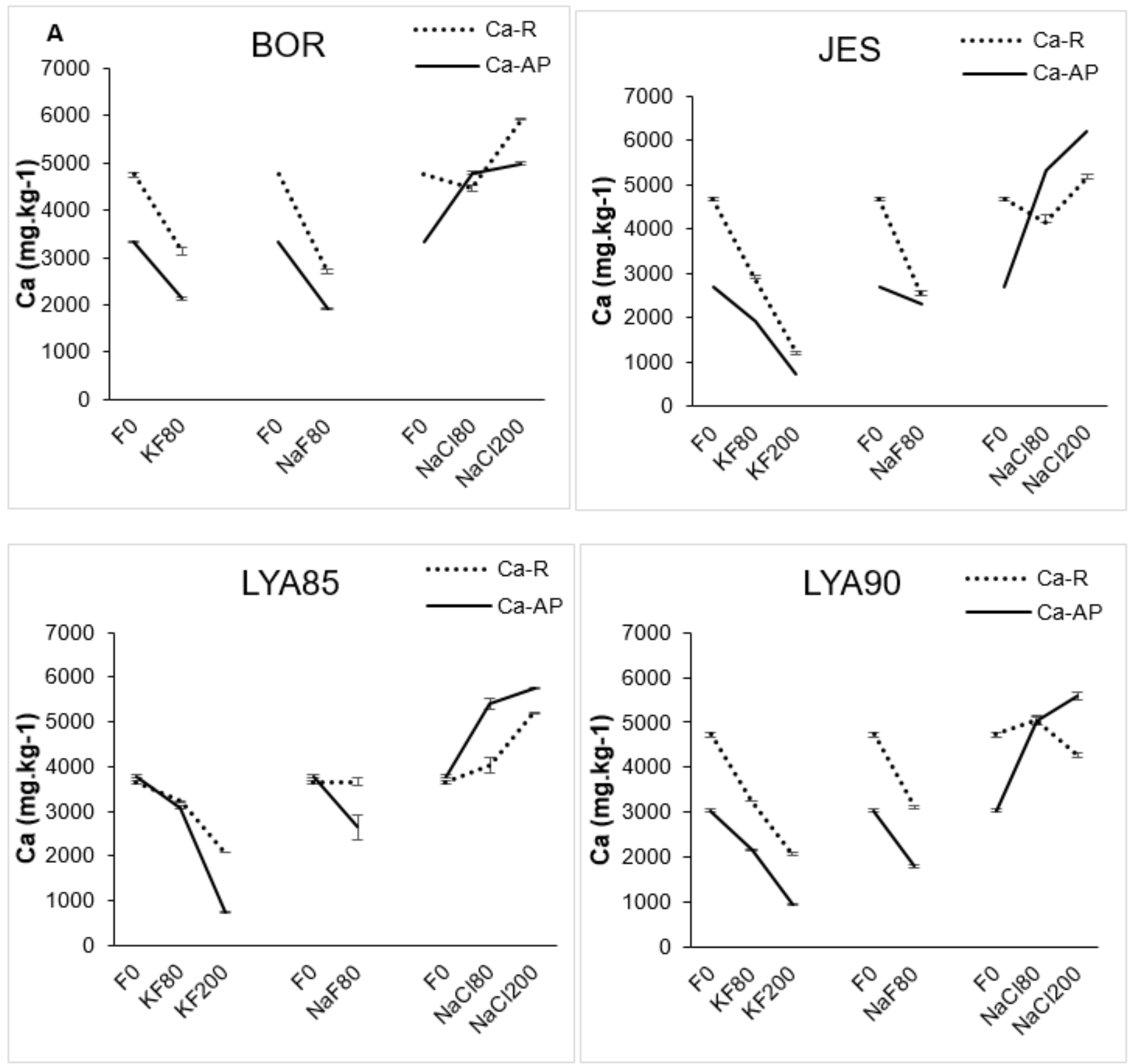

Figure 3

Effect of $\mathrm{KF}, \mathrm{NaF}$, and $\mathrm{NaCl}(\mathrm{mg} \mathrm{kg}-1)$ on the accumulation of $\mathrm{Ca} 2+(\mathrm{mg} \mathrm{kg}-1)$ in root (R) and aerial part (AP) of the four tested bean genotypes: BOR (A), JES (B), LYA85 (C) and LYA90 (D). Standard errors are shown as vertical bars. 